\title{
Correlation between Job Motivation, Job Satisfaction, and Perceived Organizational Support with Organizational Citizenship Behavior (OCB): A Literature Study
}

\author{
Robi Juli Pandra ${ }^{1 *}$, Yunia Wardi ${ }^{2}$, Abror $^{3}$ \\ 1,2,3 Universitas Negeri Padang, Padang, Indonesia \\ *Corresponding author. Email: robijulipandra@gmail.com
}

\begin{abstract}
This paper is a review study which focus to discuss the correlation between job motivation, job satisfaction, and perceived organizational support (POS) with OCB. This type of research is explanatory research, using literature review design to determine the relationship between job motivation, job satisfaction, and POS, toward the Oranizational Citizenship Behavior (OCB). The results found that job motivation, job satisfaction, and perceived organizational support had a positive and significant correlation on employees' OCB. In order to start an integrated discipline, the findings of this analysis are just a conceptual starting point.
\end{abstract}

Keywords: OCB, Job Motivation, Job Satisfaction, POS.

\section{INTRODUCTION}

Human resource is an essential asset for organizations that can encourage the improvement of other resource. Human resource determines and influences the continuity and progress of an organization to achieve its organizational goals. The same case also occurs in the organisations engaged in health care, such hospitals. An organization such hospitals, specifically a hospital engaged in psychiatric cares, it requires individual or employee who are willing to work to go beyond formal job specifications and this behavior is called extra role behavior or OCB. Furthermore, [1] also asserted that a hospital urgently needs a employees and nurses who have the ability to enhance the quality cares for patients in that they need to be motivated.

In the recovery and healing efforts of patients in the hospital, regardless of the important role of nurses. This is related to the presence of nurses who take care patients for 24 hours and the number of nurses was dominant as patients care in the hospital is about 40$60 \%$ [2]. Therefore, nurses must have good human capital to provide qualified services to improve the image of a hospital. Nurses are expected to provide optimal services to patients in order to recover patients effectively and successfully. In addition, nurses are also expected to be able to work beyond what should be done or extra roles behavior, commonly called OCB (Organizational Support Citizenship).

A good employee tends to display Organizational Citizenship Behavior (OCB) in their work environment, so the organizations will be better with employees who acted OCB [3]. OCB would have influenced the quality of services provided by employees and this affected to the performance of an organization. OCB can affect service loyalty because OCB can improve both employee interaction with the customers and service conditions [4].

These employee contributions are like helping other employees, being a volunteer for extra jobs, enforcing rules and procedures in the workplace regardless of personal inconvenience. Therefore, it can be concluded that OCB significantly influence on organizational performance outcomes and individual development. Several studies on OCB reveal that the impact of Organizational Citizenship Behavior is able to increase organizational effectiveness and success, for example low operating costs, faster work completion times, and optimal use of resources [5]. OCB also enhances the relationship between employee engagement and organizational effectiveness. As emphasized by [6], 
OCB will make an organization effective and bring new resources to them.

As [1] claimed earlier, in enhancing the quality cares for patient's recovery, nurses need to be motivated. Since employees who are self-motivated and more enthusiastic with their work take a bigger satisfaction from the work itself and continue doing their work with a feeling of satisfaction they already get. It also supported by [7], if an employee works with high work motivation, it will encourage the establishment of OCB from that employee. Employee's motivation is considered a force that encourages employees to achieve certain goals and organizational goals.

Beside motivation, to promote organizational effectiveness which is influenced by individual performance, organizational leaders can motivate employees to establish OCB by increasing employee positive attitudes, one of which is through job satisfaction and organizational support. It has already supported by a meta-analysis conducted by [8] which revealed that several individual factors were found to influence OCB including job attitudes (job satisfaction, organizational commitment, perceived support, and leader support). According to [9] job satisfaction encourages the emergence of OCB because employees with a good level of satisfaction are more likely to have emotional attitude that is fun and loving his job. This attitude is reflected by work behavior, discipline and achievement in work. [10] states that improving OCB can be done through increasing the level of job satisfaction which is usually related to some factors, including enhancing the physical condition of the work environment, interactions with other employees, and the salary received. The results of [11] had showed there was a substantial correlation between job satisfaction and $\mathrm{OCB}$.

The level of employees' OCB is also influenced by perceived organizational support (POS). POS can be defined as organizational support that convinces someone that the organization where they work has appreciated their contribution and cares about their welfare [8]. Employees who feel fully supported by the organization, then surely, they will foster a sense of indebtedness because they feel fully supported by the organization which will impact the performance and behavior of those who want to work beyond their obligations (OCB). Based on the principle of reciprocity, organizational support for employees not only helps colleagues, but also increases their own job satisfaction and organizational commitment, while reducing resignation and absences, thereby stimulating employee performance [12].

The results of researches showed that job satisfaction, job motivation, and perceived organizational support (POS) had a strong correlation with OCB. However, of these three variables, the perception of organizational support has the highest positive correlation [13]. In contrast to the research of [14], which conducted a study on the relationship between perceptions of organizational support and motivation of nurses in a hospital to work at night shifts, the results showed that there was no significant relationship between perceptions of organizational support and work motivation. In the same year, [15] found that POS positively affects OCB. Then, [16] tested the relationship between job satisfaction and perceived organizational support (POS) variables on OCB and the results were that these two variables had a significant positive effect on employee behavior.

Due to the different results found in the previous studies, researcher intend to conduct study literature in order to add depth information to the current knowledge about the correlation between job motivation, job satisfaction, and perceived organizational support toward OCB. The relationship between these variables can be seen as the figure below.

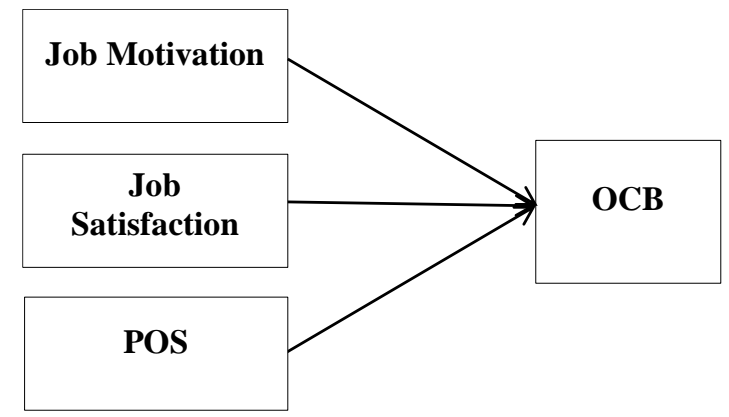

Figure 1. Conceptual Framework

\section{METHODS}

This is literature study which contains theoretical theories that are relevant to research problems. The method for this study literature is adopted from Systematic Literature Review (SRL) as suggested by [17]. SLR is characterized as a way to classify, analyze and interpret all accessible and applicable research to answer the research questions or domain topics or phenomena that become research interest. The guidelines for SLR implementation were divided into 3 stages by [17]: (1) planning; (2) executing; and (3) results analyzing.

The researchers collected the data through 3 sources on the website page: science direct, emerald insight, and Wiley intercedence. Keywords and synonyms are the strategy used by the researcher to find out the relevant articles and journal.

With the speed-reading method of all primary study applicants, the paper selection procedure was carried out. In addition, to analyze whether the paper can be used as a primary sample, the researchers divided them into inclusion and exclusion criteria. The next step, based on the expected analysis, is to implement the plan. 
Conduct web page search strings which are used as references.

Based on the searching results on the website, the data source produced 1568 papers and all those papers indirectly become primary research candidates. Then the researcher do screening to examine whether the article has the same title. It showed that 36 articles were the same as the title after screening. Of the 72 articles then screened based on eligibility, so finally only 20 articles were collected according to the inclusion and exclusion criteria.

\section{The Correlation between Job Motivation and OCB}

In general, motivation is related to the spirit of being committed to carry out such activities or obligations. Work motivation is the spirit that exists within the employees which make these employees can work to achieve certain goal. A high motivation of will influence on employee performance. Having a good performance will lead employee to have Organizational Citizenship Behavior (OCB). Job motivation significantly influence the level of OCB which indicated by the research such [18], [19], [20] and [21]. [22] also found that individual characteristics such as conscientiousness are important antecedents of OCB motives. In order to do work, motivation has a strong positive impact. Individuals who feel a higher degree of motivation appear to have high productivity. But they are going to do the job with the OCB, which is also big. Thus, when the motivation is strong, the OCB would increase, it was obvious that the motivation for the direct positive impact on OCB was based on the descriptions.

\section{The Correlation between Job Satisfaction and OCB}

Job satisfaction defined as the level of individual satisfaction in which employees get rewards in any kind of job situation from the organization where the employee works [9]. Employees who have job satisfaction has concept of fair results, treatment and procedures, there is a need for trust between employees and superiors, so employees will voluntarily act to exceed organizational expectations (OCB). Employees' job satisfaction positively influences their organizational citizenship behaviors. As the previous research indicated that job satisfaction is significantly affect and one of the strongest triggers of OCB ([23]; [24]; [25]; [26]; [27]; [28]; [29]. In addition, job satisfaction is a dominant variable which influence OCB both directly and indirecty.

\section{The Correlation between Perceived Organizational Support (POS) and OCB}

POS is such a concept of behavior where organizational support can provide an explanation of the relationship between organizational treatment, employee attitudes and behavior towards their work and organization. The treatment carried out by the organization is used as a stimulus that is captured by employees, which is interpreted as a perception of the organization's support. POS is also considered as a guarantee that assistance will be available from the organization when it is needed to carry out one's work effectively and to deal with stressful situations [8]. Employees who feel that the organizational support they obtain is strong will integrate membership into their own identification as members of the organization and then establish a more positive organizational relationship and perception. When employees felt fully supported by the organization, they will foster a sense of debt of gratitude because they feel fully supported by the organization which will impact the performance and behavior of those who want to work beyond their obligations (OCB). Based on the principle of reciprocity, organizational support for employees not only helps colleagues, but also increases their own job satisfaction and organizational commitment, while reducing resignation and absences, thereby stimulating employee performance [12] POS found to be positively related with OCB which reported in several research of [30], [31], [32], [33], [34], [35], [36]. So, from the previous researches, results illustrated that perceived organizational support has a positive and strong effect on organizational citizenship behavior and a positive association with it.

\section{RESULTS AND DISCUSSION}

After planning and execution, then the data were analyzed to find out the results. Distribution of data is achieved by evaluating data, as seen in the table below, based on years of publication, journal, and region.

Table 1. Articles distribution based on Year of Publications

\begin{tabular}{|c|c|c|}
\hline Number & PublicationYear & $\begin{array}{c}\text { Total of } \\
\text { Articles }\end{array}$ \\
\hline 1 & 2014 & 7 \\
\hline 2 & 2015 & 1 \\
\hline 3 & 2016 & 1 \\
\hline 3 & 2017 & 1 \\
\hline 4 & 2018 & 6 \\
\hline 5 & 2019 & 2 \\
\hline 6 & 2020 & 2 \\
\hline \multicolumn{2}{|c|}{ Total } \\
\hline
\end{tabular}

Table 1 showed that the number of research towards this topic has grown rapidly since the past ten years. It seemsto be more researchers will do the novelty towards this topic inthe five next years, for the result of the current study will give new assumption and enrich the knowledge. 
Table 2. Articles distribution between 2014-2020

\begin{tabular}{|c|c|c|}
\hline Number & Journal & $\begin{array}{l}\text { Total of } \\
\text { Articles }\end{array}$ \\
\hline 1 & $\begin{array}{l}\text { European Journal of Training and } \\
\text { Development }\end{array}$ & 2 \\
\hline 2 & $\begin{array}{l}\text { Worldviews on Evidence-Based } \\
\text { Nursing }\end{array}$ & 1 \\
\hline 3 & Social Responsibility Journal & 1 \\
\hline 4 & $\begin{array}{lr}\text { International } & \text { Journal of } \\
\text { Contemporary } & \text { Hospitality } \\
\text { Management } & \end{array}$ & 1 \\
\hline 5 & Chinese Management Studies & 1 \\
\hline 6 & Management Decision & 1 \\
\hline 7 & Baltic Journal of Management & 1 \\
\hline 8 & $\begin{array}{l}\text { Employee Relations: The } \\
\text { International Journal }\end{array}$ & 1 \\
\hline 9 & Journal of Knowledge Management & 1 \\
\hline 10 & $\begin{array}{l}\text { Leadership \& Organization } \\
\text { Development Journal }\end{array}$ & 1 \\
\hline 11 & $\begin{array}{l}\text { Procedia - Social and Behavioral } \\
\text { Sciences }\end{array}$ & 1 \\
\hline 12 & Procedia Economics and Finance & 1 \\
\hline 13 & $\begin{array}{l}\text { Procedia - Social and Behavioral } \\
\text { Sciences }\end{array}$ & 1 \\
\hline 14 & $\begin{array}{ll}\text { Performance } & \text { Improvement } \\
\text { Quarterly } & \end{array}$ & 1 \\
\hline 15 & $\begin{array}{l}\text { International Journal } \\
\text { Organizational Analysis }\end{array}$ & 1 \\
\hline 16 & $\begin{array}{l}\text { International Journal of Science } \\
\text { and Research }\end{array}$ & 1 \\
\hline 17 & $\begin{array}{l}\text { Global Journal of Management and } \\
\text { Business Research }\end{array}$ & 1 \\
\hline 18 & International Journal of Research & 1 \\
\hline 19 & $\begin{array}{l}\text { International Journal of Business } \\
\text { Administration }\end{array}$ & 1 \\
\hline \multicolumn{2}{|r|}{ Total } & 20 \\
\hline
\end{tabular}

Table 3 showed the number of publications by country in ten-year intervals from 2014 to 2020. Overall, of 20 articles, the study about job motivation, job satisfaction, and POS towards OCB have been done in worldwide in many sector. Most of them conducted in countries in Asia, but some also undertook in countries in Eropa.

Findings has made it clear that OCB can be caused by several factors both from individual employees such as motivation and job satisfaction as well as through factors that exist in the organization itself such as organizational support. As the results of previous studies have shown that the variables job satisfaction, motivation and POS (Perceived Organizational Support) have a very positive correlation with OCB. The relationship of these variables has been also tested in various organizations and many sectors, in that, this review study is expected to provide benefits for the scientific development of organizational behavior and human resource management, especially in the field of study regarding work motivation, job satisfaction, POS and OCB. Furthermore, the results of this study can provide useful input as material for consideration for stakeholders in an effort to establish OCB.

Table 3. Articles distribution based on Country

\begin{tabular}{|l|l|c|}
\hline Number & \multicolumn{1}{|c|}{ Country } & Total of Articles \\
\hline 1 & Finland & 1 \\
\hline 2 & India & 2 \\
\hline 3 & Hongkong & 1 \\
\hline 4 & Cyprus & 1 \\
\hline 5 & China & 2 \\
\hline 6 & Malaysia & 2 \\
\hline 7 & Thailand & 1 \\
\hline 8 & Spain & 1 \\
\hline 9 & Iran & 2 \\
\hline 10 & Bangladesh & 1 \\
\hline 11 & Indonesia & 1 \\
\hline 12 & Pakistan & 1 \\
\hline 13 & Kuwait & 1 \\
\hline \multicolumn{2}{|c|}{ Total } \\
\hline
\end{tabular}

\section{CONCLUSION}

As little work has been done in this area, the major drawback of the paper is that it is focused on a very small number of scholarly reviews. There is tremendous scope for future researchers to perform this research with primary data that would provide a full understanding of the subject matter across different cultures and various industries.

\section{REFERENCES}

[1] Engin, E. \& Cam, O. Correlation Between Psychiatric Nurses' Anger and Job Motivation. Archives of Psychiatric Nursing, 20(6), 268-275. 2006.

[2] Swansburg, R. C. Pengantar kepemimpinan dan manajemen keperawatan untuk perawat klinis. Edisi terjemahan. Jakarta: Penerbit, EGC. 2000.

[3] Markoozy, L., \& Xin, K. (2004). The Virtues of Omission in Organizational Citizenship Behavior. Draft Version 1.28.

[4] Armario, E. M. Castro, C., \& Ruiz, D. M. The Influence of Employee Organizational Citizenship Behavior on Customer Loyalty. International Journal of Service Industry Management, 15(1), 27-53. 2004. 
[5] Podsakoff, N. P., Blume, B. D., Whiting, S. W., \& Podsakoff, P. M. Individual- and organizationallevel consequences of organizational citizenship behaviors: A meta-analysis. Journal of Applied Psychology, 94(1), 122-141. 2009.

[6] Organ, D. W. Organizational citizenship behavior: The good soldier syndrome. Washington, DC: Heath and Company.1988.

[7] Shahzadi, I. Impact of Employee Motivation on Employee Performance. European Journal of Business and Management, 6(23), 159-167.2014.

[8] Rhoades, L., and Eisenberger, R., Perceived organizational support: a review of the literature. Journal of Applied Psychology, 87(4), 698-714. 2002.

[9] Robbins S. P., \& Judge, M. Organizational Behavior. New Jersey (US): Prentice Hall Inc. 2009.

[10] Nadiri, H., and Tanova, C. An Investigation of the Role of Justice in Turnover Intentions, Job satisfaction, and Organizational Citizenship Behavior in Hospitality Industry. International Journal of Hospitality Management, 29(1),33-41. 2010 .

[11] Ikonne, Chinyere N. Influence of Workstation and Work Posture Ergonomics on Job Satisfaction of Librarians in the Federal and State University Libraries in Southern Nigeria. IOSR Journal Of Humanities And Social Science (IOSR-JHSS). Vol. 19, Isuue 9, Ver IV. e-ISSN: 2279-0837. 2014.

[12] Aselage, J. \& Eisenberger, R. Perceived Organizational Support and Psychological Contracts: A Theoretical Integration. Journal of Organizational Behavior, 24, 491-509. 2003.

[13] Osman, A., Othman, Y. H., Rana, S. M. S., Solaiman, M., \& Lal, B. The Influence of Job Satisfaction, Job Motivation \& Perceived Organizational Support towards Organizational Citizenship Behavior (OCB): A Perspective of American-Based Organization in Kulim, Malaysia. Asian Social Science, 11(21), 174-182. 2015.

[14] Godwin R.,Regina I. Hubungan antara persepsi dukungan organisasi dan motivasi perawar rumah sakit $\mathrm{Y}$ yang berkerja pada shift malam dirumah sakit Y. Binus Unervisity. Jakarta. 2012.

[15] Chiang, C. F., \& Hsieh, T. S. The impacts of perceived organizational support and psychological empowerment on job performance: The mediating effects of organizational citizenship behavior. International journal of hospitality management, 31(1), 180-190. 2012.
[16] Bashan, B., \& Holsblat. R. Co - teaching through modeling processes: Professional development of students and instructors in a teacher training. Program Mentoring \& Tutoring: Partnership in Learning, 20(2), 207-226.2012

[17] Xiao, J. J., Ahn, S. Y., Serido, J., \& Shim, S. Development of a Financial Literacy Model for University Students. Management Research Review, 39(3), 356-376. http:// dx. doi. org/ 10.1108/MRR-09-2015-0216. 2016.

[18] Lazauskaite-Zabielske, J., Urbanaviciute, I. \& Balsiene, R. R. From psychosocial working environment to good performance: the role of work. Baltic Journal of Management. 2018

[19] Ahmed, S. W \& Khan, T. Does Motivation Lead to Organizational Citizenship Behavior? - A Theoritical Review. Global Journal of Management and Business Research: Administration and Management, 16(7). 174-182. 2016.

[20] Aditya, Dewa Nyoman Reza dan Komang Ardana. Pengaruh Iklim Organisasi, Kepemimpinan Transformasional, Self Efficacy Terhadap Perilaku Kerja Inovatif. Bali: E-Jurnal Manajemen Unud Vol. 5 No.3 https://ojs.unud.ac.id/ index.php/ Manajemen/article/view/17445 diakses pada 11 Maret 2020. 2016.

[21] Shareef, M. A., Mukerji, B., Ali Alryalat, M. A., Wright, A., \& Dwivedi, K. Y. Advertisements on Facebook: Identifying the persuasive elements in the development of positive attitudes in consumers. Journal of Retailing and Consumer Services, 258268. 2018.

[22] Cheung, Christy M.K \& Matthew K.O Lee. What drives consumers to spread electronic word of mouth in online consumer-opinion platforms. Decision Support Systems.2012

[23] Illie, M. P. Organizational Citizenship Behaviour, Work Satisfaction and Employees' Personality. Procedia - Social and Behavioral Sciences 127, 489 $-493.2014$

[24] Jung, H. S. and Yoon, H. H. (2015). The Impact of Employees' Positive Psychological Capital on Job Satisfaction and Organizational Citizenship Behaviors in the Hotel. International Journal of Contemporary Hospitality Management, 27(6), $1135-1156$.

[25] Gyekye, S. A. \& Haybatollahi, M. Organizational Citizenship Behaviour: An Empirical Investigation of the Impact of Age and Job Satisfaction on Ghanaian Industrial Workers. International Journal of Organizational Analysis, 23(2), 285-301. 2015 
[26] Tharikh, M. S. Managing Job Attitudes: The Roles of Job Satisfaction and Organizational Commitment on Organizational Citizenship Behaviors. Procedia Economics and Finance 35, $604-611.2016$

[27] Belwalkar, S. V. The Relationship between Workplace Spirituality, Job Satisfaction and Organizational Citizenship Behaviors - An Empirical Study. Social Responsibility Journal, https://doi.org/10.1108/SRJ-05-2016-0096. 2018

[28] Singh, S. K., \& Singh, A. P. Interplay of Organizational Justice, Psychological Empowerment, Organizational Citizenship Behavior, and Job Satisfaction in The Context of Circular Economy. Circular Economy, 1-16. 2018.

[29] Khaskheli, A., Jiang, Y., Raza, S., Qureshi, M., Khan, K., \& Salam, J. Do CSR activities increase organizational citizenship behavior among employees? Mediating role of affective commitment and job satisfaction. Corporate Social Responsibility and Environmental Management. https://doi.org/10.1002/csr.2013. 2020

[30] Chang, C. S. Moderating Effects of Nurses' Organizational Justice Between Organizational Support and Organizational Citizenship Behaviors for Evidence-Based Practice. Worldviews on Evidence-Based Nursing, 11(5), 332-340. 2014

[31] Nisar, Q. A., Marwa, A., Ahmad, U., Ahmad, S. Impact of Perceived Organizational Support on Organizational Citizenship Behavior: Empirical Evidence from Pakistan. International Journal of Research, 1(5). 2014.

[32] Islam, T., Khan, S. R., Ahmad, U. N. U., Ahmed, I. Exploring the Relationship between POS, OLC, Job Satisfaction and OCB. Procedia - Social and Behavioral Sciences, 114, 164 - 169. 2014

[33] Muhammad, A. H. Perceived Organizational Support and Organizational Citizenship Behavior: The Case of Kuwait. International Journal of Business Administration, 5(3), 59-72. 2014

[34] Han, S. H., Yoon, D. Y., Suh, B., Li, B., \& Chae, C. Organizational Support on Knowledgesharing: A Moderated Mediation Model of Job Characteristics and Organizational Citizenship Behavior. Journal of Knowledge Management. https://doi.org/ 10.1108/ JKM-03-2018-0213. 2018

[35] Merkin, R. S. Employee Life Satisfaction and Social-Capital Factors Relating to Organizational Citizenship. International Society for Performance Improvement. 2019.
[36] Tan, L. P., Yap, C. S., Cho, Y. O., Rungruang, P. \& Li, Z. Ethical leadership, perceived organizational support and citizenship behaviors: The moderating role of ethnic dissimilarity. Leadership \& Organization Development Journal, 40(8), 877897. 2019 